\title{
Emotional Competence of Adolescents from Underprivileged Socio-Economic Background
}

By Ms. Sanjoni Sethi

Amity University

Abstract- Although underprivileged groups are considered at disadvantage for capital, facilities, and utilities; very few Indian studies have made an attempt to study emotional competence as an outcome of residing in poor geographic location. The purpose of study is to understand emotional competence in adolescents of lower socio economic background. This is achieved by exploring emotional aspects of personality, emotional triggers, skills to regulate emotions and coping mechanisms. Semi-structured interviews as part of body map, a qualitative tool was carried out with six adolescents from underprivileged background. Interpretative Phenomenological Analysis (IPA) was used to analyze transcripts along with body maps of participants. Overall, research findings reveal that location does effect emotional competence in adolescents. Further, emotional competence is not age appropriate suggesting clinical implications for adolescents from underprivileged background.

Keywords: emotional intelligence, body maps, underprivileged, adolescents, sociological conditions.

GJHSS-C Classification: FOR Code: 160899

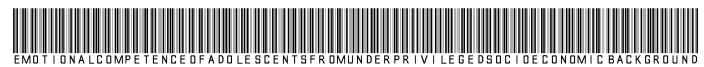

Strictly as per the compliance and regulations of:

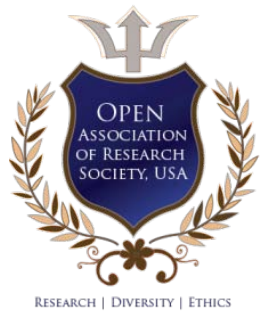

(C) 2020. Ms. Sanjoni Sethi. This is a research/review paper, distributed under the terms of the Creative Commons AttributionNoncommercial 3.0 Unported License http://creativecommons.org/licenses/by-nc/3.0/), permitting all non-commercial use, distribution, and reproduction in any medium, provided the original work is properly cited. 


\title{
Emotional Competence of Adolescents from Underprivileged Socio-Economic Background
}

\author{
Ms. Sanjoni Sethi
}

\begin{abstract}
Although underprivileged groups are considered at disadvantage for capital, facilities, and utilities; very few Indian studies have made an attempt to study emotional competence as an outcome of residing in poor geographic location. The purpose of study is to understand emotional competence in adolescents of lower socio economic background. This is achieved by exploring emotional aspects of personality, emotional triggers, skills to regulate emotions and coping mechanisms. Semi-structured interviews as part of body map, a qualitative tool was carried out with six adolescents from underprivileged background. Interpretative Phenomenological Analysis (IPA) was used to analyze transcripts along with body maps of participants. Overall, research findings reveal that location does effect emotional competence in adolescents. Further, emotional competence is not age appropriate suggesting clinical implications for adolescents from underprivileged background.
\end{abstract}

Keywords: emotional intelligence, body maps, underprivileged, adolescents, sociological conditions.

\section{InTRODUCTION}

motion is dynamic and it constitutes multiple aspects. It is characterized as a physiological as well as social phenomenon (Silva, 2006). It is a state of physiological arousal which evoke emotional experience in response to one's biological drives. On the other hand, emotions allocate a significant value to an individual in relation to belief system; cultural connotations and social considerations. Izard (2007) defines emotion to be a "system of social communication" (Izard, 2007, p.264). Displayed emotions (example, aggression; crying; and smiling) communicate subjective experiences felt by individuals in order to evoke response from others present in their social environment.

Human survival is based on three properties of emotion, organization; motivation; and regulation. It is suggested, emotion influences personality. It is often observed certain individuals are capable of experiencing some emotions more frequently than the rest of us. For example, anger experienced often by individuals following expression of such emotion into practice makes it a part of their personality by others. Thus, many educationists time and again put forth that personality acts as a significant predisposition in experiencing emotions (Hume, 2008). For instance, individual readily experiencing guilt and fear while their peers stay calm in the same situation depicts the frequency of experiencing

Author: M.Phil Trainee (RCl Approved, Institute - Amity Institute of Clinical Psychology (RCl Approved), Amity University, Gurgaon. e-mail:sanj3094@gmail.com emotions vary amongst individuals. Personality holds a trait component predominantly is involved in emotional experiencing (Hume, 2008).

In addition to experience, individuals can also be predisposed to experience emotion in varying intensity such as experience emotions more intensely than others do. For example, the way individuals respond differently in a cinema set up. An individual continues to cry after a movie while others remain calm on feeling the sad emotion few hours ago.

Professionals and scholars in Psychology begin to understand emotion from an evolutionary approach, Darwinian perspective (1872) (Cornelius, 2000). The evolutionary perspective emphasizes on the survival value attached with emotions. Contemporary theories of emotion explain the universal existence of facial expressions. In particular, six of such emotions are identified, happiness, sadness, fear, disgust, anger and surprise known as the "Big Six" (Cornelius, 2000). These primary emotions have high functional value because of the adaptive role in survival and in emergence of other emotions.

Further to Darwinian perspective, physiological theories of emotion include Lange (1967), proposed three aspects or components to emotions, cognitive; actions; and feelings, respectively. Lange's theory suggests that actions of the body contribute to one's emotional feeling. Other theorists have proposed other physiological and cognitive explanations for the same.

Contemporary theorists adopt social constructivist approach which is diverse in nature. Averill (1980) purposes emotion to be an outcome of learned socio-cultural norms. Embedded in both, western and non-western societies; these emphasize role of social relationships; interpersonal and intrapersonal issues; and adaptive functioning of personality. Averill characterizes emotion such as anger to be socially rooted to form an individual personality (Cornelius, 2000). In addition, Stets and Turner (2005) emphasize the interplay between social structures which affect emotional arousal. Sociological analysis reveals social setting (location) influences individual emotion. Universal characteristics and cultural variations both have an impact on bodily sensations of emotions (Poortinga, 1992).

Similarly, developmental theorists argue various aspects of personality for survival purposes should be strengthened from early childhood. Saarni (2011) 
explained emotional development milestones in relation to social interaction in children. According to Saarni, middle childhood (7-10 years) shows advancement in problem solving strategies; start appreciating norms and become aware of multiple emotions. While development of knowledge of emotion scripts (social sensitivity) occurs in preadolescence (10-13years). Therefore, achievement of emotional skills is a developmental process which does not occur in isolation. It is cultivated and reinforced by social context.

Certain emotional skills mature and strengthen in particular age range (Saarni, 2011). Typically, adolescents recognize various emotional strategies to perform in daily life. Further, researchers have found emotional intelligence to be shaped by family and society in the Indian context (Sibia, Misra \& Srivastava, 2004). Recent study by Bilc, Cioara and Miu (2015) concluded emotional regulation was highly affected in children from poor social community. The contemporary understanding of rural community (poor economic status) is not restricted and limited to the lower income family. Rural community as individuals residing in living conditions where, there is lack of schooling; limited access to transportation; partial or minimal medical services and other civic utilities; and physical isolation. Thus, a child's development is considered to be affected by situations that make them suffer through emotional distress (Schreuder, 2010). This could result in an emotional handicapped adult later in life. Thus, there is not sufficient research which compares emotional competence strategies in adolescents. In order to achieve this, the present research will use embodiment of emotional aspects. The goal is to explore how social conditions influence emotional development in children. The research purports to understand emotional competence in adolescents of lower socio economic background.

i. To understand the emotional aspects of personality shaped by sociological conditions.

ii. To identify emotion triggers and strategies for emotional regulation/expression.

iii. To explore the coping strategies of underprivileged children.

\section{Literature ReVIEW}

Literature includes recent works of contemporary authors along with works of evolutionary theorists on emotions. The study reviews work published since late twentieth century (1970's onwards) to present empirical work.

Emotional competence is an essential concept in contemporary times considered to be a fundamental feature of personality. It comprises of emotional identification; regulation and evaluation in any context. Poor living conditions include limited admittance to educational services; provision of medical measurements and poor cognitive skills. The physiological domain depicts changes in neurostructural mechanism in relation to body-emotion experience. While, constructivist aspect explores social engagement. Adolescence is the primitive and vital age group which goes through frequent and intense emotional changes. Neurobiological alterations experienced in this age are associated with increased emotional vulnerabilities. In comparison to others, adolescents show social reorientation in brain areas (Telzer et al., 2014). The process of socialization was studied using brain scans of both, parents and adolescence to understand the role of emotions. Telzer (2014) mentions social environment (eg: parents) influence emotional competence in adolescence.

The ability to manage one's emotions in sociocultural locale is a significant requirement in an intercultural setting. Lanteigne (2011) found socio emotional problems in adolescents (male and female). He categorized it as 'Suppressive' (high experience, high arousal, low expression), the adolescent participants display social anxiety; avoidance and nonacceptance of their emotions. This makes them competent for job interviews, however, inhibits their social interactions to make friends. The 'Experience Expressive' (high experience, low arousal, high expression) have limited awareness about emotions hindering regulatory behavior (Lanteigne, 2011).

Further, it was found that adolescents who have the inability to identify, describe and express emotions in families with lower levels of cohesion are clinically labelled as alexithymic(Telzer et al, 2014). Selfconscious emotions such as shame and guilt are considered to be socio-culturally consistent when it comes to expression and interpretation (Scheve \& Luede, 2005).

According to Frank (1988), when individuals suppress emotions, it could negatively affect formation of coalitions, negotiations, collective teams and actions within a social group. Irrespective of location, school going adolescent girls of Karnataka were found to have problematic behavioral conduct. Researchers screened 120 urban and 120 rural adolescent girls (school going and non-school going) using SDQ (strengths and difficulties questionnaires) assessing five behavioral scale constructs (conduct problems; hyperactivity; emotional symptoms; peer problems and pro-social behavior). These scales were positively correlated with fear; aggression; and sadness. Further, they found rural girls do not readily share their difficulties (Dhoundiyal \& Venkatesh, 2009).

Until now, SES was characterized by financial domain. However, contemporary theorists define SES as difference which exists in availability and use of resources between higher and lower SES. It is perceived as services, facilities, parental opportunities and goods which are provided to children from a high SES family in 
order to better their living conditions (Brooks-Gun \& Duncan, 1997). For a holistic understanding of SES, it is important to consider other co-occurring factors including mental illness and hazardous environmental conditions. These co-factors mediate the effect of SES further (Garbarino, 1999).

Biopsychological perspective confirms literature on association between childhood poverty and emotion dysregulation. Kim et al. (2013) found negative physical and psychological associates of emotion with adult neuronal processes. Children who were born in poverty conditions, showed emotional dysregulation in adult life because of the reduced prefrontal cortex activity in brain and poor suppression ability of amygdala (Kim et al., 2013). On the other hand, National Centre for Children in Poverty (NCCP) reported lower income family characteristics can negatively affect socio-emotional development in children. This negative affect often results in behavioral problems; emotional dysregulation and poor comprehension (Cooper, Masi \& Vick, 2009). Maladaptive functioning, vulnerability of depression and acts of delinquency are often observed in low SES adolescents (McLoyd, 1997). Child abuse, aggression among peers and violence in community settings are often witnessed by low SES children (Garbarino, 1999). Social order is reduced in lower SES due to existing cofactors explained by social disorganization theory (Sampson, 1992).

A survey investigation by Jamadar and Sindhu (2015) on tribal adolescents of Karnataka found emotional intelligence and creativity being impacted by socio-economic status. Higher SES showed better emotional intelligence and creativity as compared to lower SES. Further, adolescents aged16-19 years were better than $12-15$ years.

Body mapping allows embodying emotions of traumatic experiences (Crawford, 2010). The activities designed allows emotional expression in children creatively (Hemmings, 1995). It is partially considered to be a child centered methodology (Mitchell, 2006; Gamlin, 2011). Children working in labor fields and residing in poverty embodied their illness to their bod and social context. Thus, body maps seem to be an explorative instrument for this research, especially to be used with children. The selective advantage of the tool is detailed account of experience obtained.

\section{Methods}

\section{a) Research Method}

A qualitative research design has been used. The key feature of a qualitative paradigm is phenomenology. The research followed an exploratory qualitative research design which allows understanding of context; flexibility; personal experience and subjective interpretation.

\section{b) Participants}

The researcher used general health questionnaire (GHQ) to screen the access population. Participants consisted of a mixed sample of six adolescents aged 10 - 15 years. Participants were recruited after theoretical saturation was reached. These adolescents were residents of low SES. Rapport was established prior to the commencement of research and during body mapping interview. Participant criteria included, adolescents residing in low SES since birth; attending school and at least one of the parent employed. Further, age and communication in basic English/Hindi are essential. In order to avoid dropouts, a dance-movement training session for underprivileged adolescents. Additionally, data collection took place at the venue of the participants reducing traveling and other cost influences.

\section{c) Sampling Technique}

A mixed sampling method was adopted. Researcher identified adolescents from lower geographic SES to comprise target population. Prior familiarity and convenience sampling allowed to draw out accessible population. Further, stratification was used to differentiate family compositions including, single parent; and working parents. Finally, purposive sampling was used to select the sample.

\section{d) Instruments}

Body mapping is a multipurpose qualitative instrument adapted by Solomon (2002) as a narrative process to understand the story of HIV women living in Cape Town, South Africa. It is considered to be an artbased therapeutic tool. Participants communicate their overall story via creation of different symbols and meanings attached to their experience (Gastaldo, Magalhaes, Carrasco \& Davy, 2012). A body map is a life - size representation of one's self using different symbolic slogans in order to put across one's experiential story. Davy et al. (2014) states body mapping allows data collection in a creative manner without causing any harmful conditions in a confrontable approach (Davy, Magalhaes, Mandich, Galhiego, 2014). Based on research design, this semi-structured interview used three key elements, a testimonial (first person narrative experience); a life size body map; and defining characteristics of visual representations. Researcher established an interview guide based on the three objectives of the study. Each participant took part in three individual sessions of one hour each. Homework was also assigned to participants. This research used body manual procedure and guide adapted by Gastaldo, Magalhaes, Carrasco \& Davy (2012) which provides more flexibility; detailed manual and ease access to guide. It permits use of manual for research purposes. 


\section{e) Procedure}

Intrigued by western traditions on emotions, researcher reviewed past literature. Foremost, researcher took written/verbal permission from University, head of SES area, parents and adolescents. Then rapport was established with community members. Later, data collection inclusive of informed consent; obtaining demographic details; instructing on interview process and creating body maps. In the end participants were debriefed to ensure no harm or damage. The collected data consisted of transcripts and video recordings. The transcripts included interviews, body map, observation memos and homework/session scripts. Transcripts were validated by participants.

\section{f) Analysis of Result}

Foremost, interviews were transcribed and Interpretative Phenomenological Analysis (IPA) performed. IPA, developed by Smith (1995) to discover social cognitions in individual experience. It focuses on ascribed meaning put forth by participants in relation to environment. Interviews were transcribed tracing symbols, language, body postures and colors used by participants. Notes and homework scripts were supporting evidences. Objectives and responses were important to create preliminary themes. Researcher created codes manually by re-reading transcripts. Themes were grouped and sub-ordinate themes were identified. Divergent themes were listed to explore further. Finally, themes were tabularized and interpreted.

\section{g) Ethical Approval and Informed Consent}

A written proposal was submitted and a pilot was conducted. Data audit was conducted at Christ University by Professors to give the ethical consent. Informed consent was taken in writing and verbally. Participants were shown an exemplar body map to avoid use of names of individuals, and location. Standardization was maintained as same interview guide was used for participants. No monetary incentives were offered. Instead, a dance movement workshop was given. Incentive of this nature is considered to be a reimbursement to the research participants for completing the process and is accepted by the government and industry sponsored research trials (Zweben, Fucito, O'Malley, 2009). At last, participants were debriefed. Anonymity and confidentiality were maintained. Triangulation technique was employed to analyze data to avoid liner understanding. Researcher followed code of ethics enlisted by American Psychological Association and Body Mapping Manual.

\section{Results and Discussion}

The studyaims to explore how social conditions influence emotional development in children. The first participant is a 13 year old boy who explores meanings, identifies colors and interprets situations in light of health care. He constructs his desires influenced by financial concerns. He bears responsibility of challenges affecting his personality. 'Black Color' is selected to trace body outline which makes participant feel "dull" and is also a representation of his "skin color" as informed. Although participant began sharing positive aspects about black color, he connotes black with dullness. He further defines dullness to be equivalent to sadness. Non-western countries like Japan find color black associated with lower social status. It is deciphered as a sign for societal disruption, dirt, unpleasantness and crime (Russell, Wilson, Hall, 1992). Participant represented this on his body map with red color as indicator of anger. Darker colors are closely associated with negative emotions like sadness and anger (Boyatzis \& Varghese, 1994). Red color is considered to be stimulating in nature (Ballast, 2002).

Participant projects anger onto other people even in context of smoking in slum. He chooses to rationalize his anger as he observes others to do the same in slum. 'Defenses' and "health' are important themes. He finds breathing concerns for all school goers due to smoke in their area. Color-emotion preference like for participant is associated with contextual setting(Pope, Butler, Qualter, 2012). Dialysis treatment of his father and smoking has instilled fear and pain in participant. He finds sadness to emerge when there is pain. Red color is associated with anger, while black is strongly associated with fear, sadness and disgust (Mohammad, 2011).

Romano (1976) found that children in cases of parental illness suppress their emotions as they begin to take on the role of care takers for their parents (Romano, 1976). Participant states, "I do not think about pain" and represented this on his legs in the body map. He has represented them outside of his body. He clearly conveys am opinion and visually ranks it the lowest. He prioritized his father's health on the chest and wrote a moral message for shopkeepers selling cigarettes on the legs. In this situation of stress, participant finds his strength and support from God, parents and friends.

Participant created a cross near his heart on the map to symbolize God. He drew a sofa to symbolize two essential figures, his father and house. He describes this symbol to be "soft" so he can easily sleep on it. Participant might indicate his father's sensitive condition or mirror the needs he desires from his ill parent. Research reveals that children with parental illness could be anxious, depressed, fearful, risk of getting the condition, and show changes in socio-behavioral patterns (Aldrigea \& Becker, 1999). There is also a need for achievement in participant to earn money for his father's treatment. Romano (1976) found not only emotional suppression in such children but false maturity takes place. Participant adopts the care taker role during such stressful conditions. He takes 
responsibility of the house and acts as 'man of the house' (Romano, 1976).

Coping is one of the themes for participant. He resorts to playing cricket to settle himself. He marked "tension" in brain on his map as "covert marks". To cope with his he focuses his energy on his game. He states, "whenever anyone is sad, they should do what they like". At last, participant struggles between real versus ideal. He expects clean roads, smoke free area, and no fights in his slum. However, the opposite is true. Similarly, his personal life mirrors external environment. He expects honesty, bravery, good health and unchanged relationships with friends,

In summary, participant inclines to emotions such as anger, fear and sadness with regard to sociological conditions of residence. His father's health condition and local habit of residents seem to be emotional triggers which he expresses as signs of tension. He has strong defense mechanisms that might appear to provide immediate gratification, however, could become maladaptive coping patterns. Other coping strategies include faith in God, friends and hobbies (eg: cricket). Researcher understands participant views place of residence, socio-economic status and family condition (eg: primary male figure's ailment) as significant contributing factors to the presentation of negative emotions.

The second participant is a 15 year old boy with a similar family condition. His father suffers from a kidney failure. Participant also traced his body with black color narrating how he finds "home to be black, outside to be black and his body". Particularly, undesired emotions are closely related with the color black (Boyatzis \& Varghese, 1994). Participant associates with black color at home, in his area and within his body. It might indicate darkness in these three domains. His feelings reflect three emotional states. There is anger associated with his area, loneliness within himself, and sadness with regard to his father's dialysis condition. This could suggest that these three are influential aspects.

Participant experiences "all night disturbance" in his area which causes distresses. He states, "people are not nice here" and wants to change. He represented this on his chest in the map. He also drew tress on the chest for healthy living. There is a dichotomous relation between life and death. He pasted, "keep surrounding clean, don't drink and don't smoke" outside of his body trace. He tries to block the outliers in his life which harm him or his loved ones. 'Health' is an important theme for participant. Emotional distress in children affects their development (Schreuder, 2010). Possibly participant finds himself to be responsible for his father and family's health. He disclosed to avoid sharing about 'marks' on his body with family members. It was his way to not "scare" them. Although suppression can have negative effects, it is also a mature defense mechanism (Bowins,
2004). Suppressing emotional experiences result in negative coalitions, negotiations and actions in a social unit (Frank, 1988). Family for participant is a critical social unit. His family resembles an enmeshed family system. Participant's attachment is represented by a ring on body which has his parent's initials on it. He also states he "does not want to lose them". His faith in God has helped his family reduce their problems. People from lower SES report more psychological benefits from religiosity (Ellison, 1991; Krause, 1995).

In summary, participant inclines to emotions such as anger, loneliness and sadness with regard to the sociological conditions of area and home environment. His father's health condition, separation from loved ones, and lacking a sense of belongingness seem to be emotional triggers regulated by emotional suppression. His coping strategies include faith in God, friends and constant parental support. Researcher understands participant displays bipolar emotions.

The third participant is a 13year old girl who used meaningful symbolism to describe herself. Her financial situation influences her life. She created a wall on her chest describing as weak. This causes "fear" and "tension" experienced physiologically as well. Body maps allow communication of emotions by embodying visually (Hemmings, 1995; Crawford, 2010). She narrates, "we don't have our own house" suggesting physical and mental insecurity. The need for protection and safety is the basic necessity after physiological needs in one's life (Maslow, 1943).

Participant lacks a significant figure in her unsafe house. As she shares, "my mother has fever and we have spent on it... she wants to make me doctor but we don't have money". Health, money and education remain dominant themes. A house can provide shelter and a guardian can offer personal protection (Maslow, 1943). Family condition makes participant helpless. Her elder sister seems to replace primary role models. Participant idealizes physical appearance such as "long hair and big eyes" of her sister to the extent she incorporates her color preferences for tracing. Family members influence emotional competence is adolescence (Telzer et. al., 2014).

Participant chose an anklet as her symbol to describe the variations in her mood. She stated, "One time my mood will be angry, at that time anybody will talk to me, l'll hit them." Rural school going girls displayed behavioral concerns like short tempered and fights (Dhoundiyal \& Venkatesh, 2009). Lack of secure attachment could cause participant to react. Insecure attachment, inadequate parenting and stressful conditionstrigger aggression in impoverished families. It is a consequence of maternal hostility (Renken, Egeland, Marvinney, Mangelsdorf \& Sroufe, 1989).

Participant also shows her disapproval to the marks on her body. She drew some near her eye and legs in the map. She wanted to free herself from the 
bandages, "I was thinking I should open it and I should be free." Physical appearance in early adolescence is an important aspect forming global self - esteem (Harter, 1990). She mirrors her struggle to be free from the stressors at home as well. At formal operational stage of Piaget's theory, participant fantasizes a bigger house, trees and makes herself the center of attention. Behaviors such as daydreaming, self-consciousness, and exhibitionism are examples of adolescence ego centricism (Galanki, 2001).She imprinted her hands with black color as "skin color". She also worried about socially being judged by research as informed in first interview. Remarks by family and peers effect in cognitive appraisal of children about themselves and identity (Robinson, 1995).

Participant shows increase likelihood to be around friends and seek reassurance. Intimate peer relations and peer acceptance to be of increased concern to adolescents (Crockett et al., 1984; Furman \& Buhrmester, 1992; Veronneau \& Dishion, 2010). She often cries in isolation when hurt and expects peers to show concern. Participant also writes about her thoughts and feelings. There is a need of belonging and a space to vent. At the end of the interview she also stated, "what in my heart I said you all and my heart is free". Body maps allow communication of emotions especially as a child centric tool (Gamlin, 2011).

Thus, various emotions emerge in participant's personality with regard to her sociological conditions governing at home. Emotional triggers include unstable relationships; and change in routine. Participant engages in various emotional expressions such as fighting and crying considered immature ways of coping. Overall, researcher finds lacking ability to reintegrate emotions along a spectrum.

The fourth participant has been brought up in a conservative family since 15 years. She seeks parental approval for her choices and demonstrates family idealization. The participant narrates her journey growing and learning in the four walls of her house. 'Family' is an important theme for participant. It is both her symbol for home and life visually represented in the heart. She finds herself extremely happy when around family such that she "prefers to stay with her family only". There is a secure attachment base in the family and the participant feels protected. Excessive security could also lead to dependence. Dependency in children is acquired when gratification is achieved by attention, approval, help and facial gestures of the significant other (Ainsworth, 1969). There are unsaid family rules, "when elders of the family talk, we are not allowed to speak."

Parents extend idea of protection in wearing black threads on body. Participant drew on her ankle, wrist and neck in map. It is observed as a common practice in slums to use different mediums to protect neonates and children from evil eye such as using plastic bangles, anklets, and kohl (Dubey \& Desetty,
2015). Participant believes in house ownership and territorial protection. House ownership is considered to be a status symbol which increases family pride, security and expression (Linneman and Megbolugbe, 1993). 'Attachment' is an important theme amongst friends and family for participant. She hurts herself when friends or family members disappoint her and are in pain themselves. Although participant forms secure attachment, she suppresses herself to share feelings. Adolescence suppressing emotions indulge into avoidance as they are not able to regulate internal experiences. They are self-conscious (Lanteigne, 2011). Guilt was observed during interviews in participant to lack ability to do something for her family. Guilt and shame are two self-conscious emotional expressions (Scheve \& Luede, 2005).

Participant identifies abusive language, fights and alcoholism to be the issues her parents want to protect her from. Social order is also found to be reduced in such areas (Sampson, 1992). She does not find the right way of addressing these concerns. She appears to have low confidence because she finds herself "with no courage". This could be a result of overprotection by parents. She wants to change society but finds people do not to listen to her which is symbolic to her situation at home due to an enmeshed family system. Participant's emotional competence has only been nurtured around her attachment figures. There is emotional redundancy due to limited exposure witnessed. Emotional expression takes place in the form of crying spells and self-harm while maladaptive coping strategies are being used such as suppression. Researcher observed vulnerable personality traits including dependency as her family culture.

The fifth participant is a 13 year old girl who narrates her experiences on being molested by family and strangers. She finds no symbolic meaning in objects that could be associated with her. She felt disgust during body tracing. However, she gradually changed her opinion.

Participant was molested by her maternal uncle. She recalls he "touches everywhere". It instilled fear in participant. She worries, "people in my area will beat me, I am full scared". Children who are sexually bullied have greater psychological issues and the risk is greater when it is a relative (Kumar et al., 2012). Participant traced her body with a dark color and chose the heart to write about her experience. Darker colors are associated with negative emotional relations (Hemphill, 1996). Participant shows anger towards people in her slum, "feels bad when they touch me and want to slap them". She identifies molestation and fights to be core concerns. She depicted these acts with a negative symbol with a color she dislikes. Contextual factors play a role in color selection. Emotions and color share a reciprocal relationship combined with cognition, it brings in feelings and memories of a particular situation (Wiesel 
\& Daphna - Tekoha, 2000; Elliot, Maier, Moller, Friedman, \& Meinhardt, 2007).

Participant has no contact to vent. She found this interview helpful as stated, "today I will be sharing it, I can't tell this to anyone, I'll feel bad. She uses suppression, self-talk and crying to release her pain. Rural community girls are also found to not share their difficulties (Dhoundiyal \& Venkatesh, 2009). She finds difficult to relate with objects in her environment. This might indicate her helplessness as she narrates, "I can't do anything". This extends to primary family members who fail to make her feel secure and special. Participant might be unable to cope with cognitive discrepancies and uses neurotic defenses. These are used when individuals are experiencing internal or external created stress (Bowins, 2004). Family conditions create pressure for participant to use self blame. She blames herself to be a burden on her family. She dislikes to perform household chores such as "wash clothes and wash utensils" as a girl child. Unfortunately, participant finds her support from God and herself.

Participant expresses fear and anger as part of sociological conditions at home and community. She practices self-harm and crying. These are triggered by molestation and household expectations. Self - criticism and self - blame might be consequences of her trauma. Current arguments at home and belief systems reinforce such acts as participant focuses on death measures as escape.

The sixth participant is a 14 year old girl. She struggles with financial difficulties and marital discord between parents. While there are these concerns, participant finds parents to be supportive. She has a secure attachment with family and friends. She traced her outline with color preference of a deceased childhood friend. She cherishes her dad's wallet as a symbol. Her father is the bread earner and she clearly understands constrains.

Participant bears responsibility of resolving conflicts between parents at home. Participant shows higher self-conscious emotions like guilt (Scheve \& Luede, 2005). She feels guilty, "I am the daughter that is why guilty". Participant reflects monetary gain a son can add to the value compared to a girl in family. Along with family concerns, participant finds she relies on parents to safeguard her from eve-teasers in slum. She drew a red color face depicting anger. She adds, "wants to slap them".

Protection is an essential theme. Participant wears a black thread on her neck to protect herself. She created a prayer book as a symbol to safeguard family. She wrote her prayer, "please protect me" as a core belief. Participant uses burkha to provide her courage and makes her feel safe as she is covered. Participant resorts "crying to god" for any stressful condition. Lower SES shows higher religious coping (Krause, 2003), connect (Krause, 2002), and interaction (Pollner, 1989).
Participant shows fear, helplessness, and guilt as part of her emotional personality. The sociological conditions triggers include eve teasing and fights. She uses multiple mediums to feel protected. Researcher suggests participant does not have mature developed ways to express emotions except crying. She requires scope for emotional ventilation, self-awareness and ways to express.

While each story has an idiographic representation of participant emotions, feelings, and struggles; there are some common elements which have been revealed. All six participants have experienced three primary emotions, anger, sadness, and fear. These three emotions are considered undesired or pessimistic emotions. This indicates participants from lower SES are vulnerable poor emotional affect. NCCP finds negative affect between lower income groups and socio-emotional functioning (Cooper, Masi \& Vick, 2009). In fact, two participants also exhibited self-conscious emotions which are found to be socially consistent.

Participants used darker colors known to elicit undesired emotions and act as activating stimulants. Likewise, three categories of emotional triggers include, stressful life events; issues in area; and challenged needs. The first trigger is a combination of financial difficulties and health concerns in families. Participants expressed financial challenges faced to educate themselves. Deprivation affects self-concept and selfesteem due to lack of education as a result of personal and social relations (Kundu, 1984). The second trigger is a combination as eve-teasing, fights and garbage. The third trigger focuses on safety needs such as attachment and safe neighborhood.

To regulate emotions, participants use strong defense mechanisms. Suppression and isolation have been commonly used by participants. Two common emotional expressions include crying and aggression. Aggression was visible in fights, communication and self-harm. Participants do show emotional awareness about existence of multiple emotions. However, it lacks insight in relevance to social roles. Therefore, participants present emotional skills usually mastered by children in their middle childhood (7-10 years). Few participants show pre-adolescent emotional development (11-13 years) (Saarni, 2011). Personality characteristics; family support and external support contribute to resiliency factors (Garmezy, 1993), Participants use coping strategies to overcome challenges in slum. All participants reported faith in god helped them and their families. Thus, the research findings provide concrete examples of how sociological space such as location can elicit certain emotions in individuals and affect emotional competence in adolescence development. 


\section{Summary And Conclusion}

Research purports to understand emotional competence of adolescents and social condition affects emotional development. Findings reveal that location may affect emotional competence in adolescents. Primary emotions identified are fear, anger, and sadness which arise due to stressful life events, issues in sociological environment, and challenged needs of participants. Participants show limited awareness of these emotions and do not regulate them age appropriately. Emotional expression includes aggression, crying and self-harm. Overall, coping mechanisms include support systems, religiosity, and personality characteristics not being used to potential.

\section{a) Implications}

The findings can be used to increase awareness in parents and teachers of underprivileged areas about maladaptive patterns. It also allows to study emotional reactions as a result of location triggers. Further, clinical implications include use of body maps as a therapeutic tool. Participants reported body maps allowed them to express their emotions. It provided a space for ventilation and acted as a process of catharsis. At last, body maps can be used for educational purposes.

\section{b) Limitations}

Body map is a new tool, neither exhaustive literature is available nor do many professionals know of its use. The interview is divided into three segments for each participant. This makes participant availability difficulty and increases chances of drop-outs. At last, tool incurs costs for the material.

IPA includes subjective bias of researcher which is a weakness. Double hermeneutics as a criticism of IPA is valid in analysis of results as well as during data collection. Although sample size is small, data collection and analysis has been in-depth for each participant.

\section{c) Future Recommendations}

Future research studies can assess therapeutic value of using body maps. A comparative study between economic groups could help to understand use of coping skills and emotional competence in children. At last, gender specific emotional expression based on locality studies are also recommended.

\section{AcKnowledgements}

I grateful to my supervisor, Mr. Harishankar Moosath, Assistant Professor, Department of Psychology, Christ University. His constant support and constructive feedback helped me incorporate various perspectives. Furthermore, I would express my gratitude to all participants and their families for investing time, emotions and disclosing personal information. Also, I would extend my token of appreciation to Mrs. Hussain,
Principal, Greenland Public School for granting permission to use school premises for data collection.

\section{Role of Funding Sources}

There was no funding source involved in the study design, collection, analysis or interpretation of the data, writing the manuscript, or the decision to submit the paper for publication.

\section{References Références Referencias}

1. Ainsworth, M.S. (1969). Object Relation, Dependency, and Attachment: A Theoretical Review of the Infant-Mother Relationship. Child Development, 40, 969-1025

2. Aldridgea, J., \& Beckerb, S. (1999). Children as carers: the impact of parental illness and disability on children's caring roles. Journal of Family Therapy, 21, 303-320

3. Averill, J. (1980). A constructionist view of emotion (In Plutchik, R. and H. Kellerman, editors). Emotion: Theory, research, and experience. New York: Academic Press

4. Ballast, D. K. (2002). Interior design reference manual. Belmont, CA: Professional Pub. Inc

5. Bowin, B. (2004). Psychological Defense Mechanisms: A New Perspective. The American Journal of Psychoanalysis, 64, 1.

6. Boyatzis, C. J., \& Varghese, R. (1994). Children's emotional associations with colors. Journal of Genetic Psychology, 155, 77-85.

7. Brooks-Gunn, J., \& Duncan, G. J. (1997). The effects of poverty on children. Future Child, 7, 2, 55-71.

8. Cooper, J. L., Masi, R., \& Vick, J. (2009). Socialemotional Development in Early Childhood: What Every Policymaker Should Know. National Center for Children in Poverty, Mailman School of Public Health, Columbia University.

9. Cornelius, R. R. (2000). Theoretical approaches to emotion. Proceedings from ISCA Tutorial and Research Workshop on Speech and Emotion. Northern Ireland, UK: Newcastle University.

10. Crawford, A. (2010). If "the body keeps score": Mapping the dissociated body in trauma narrative, intervention and theory. University of Toronto Quarterly, 79, 2, 702-719

11. Crockett, L., Losoff, M., \& Petersen, A. C. (1984). Perceptions of the peer group and friendship in early adolescence. The Journal of Early Adolescence, 4, 155-181. doi: 10.1177/0272431 684042004

12. Darwin, R. (1872). The expression of emotions in man and animals. London: Murray.

13. De Jager, A., Tewson, A., Ludlow, B., \& Boydell, K. (2016). Embodied ways of storying the self: A systematic review of body-mapping. In Forum 
Qualitative Sozialforschung/Forum: Qualitative Social Research (Vol. 17)

14. Dhoundiyal, M., \& Venkatesh, R. (2009). The psychological world of adolescence: A comparative evaluation between rural and urban girls. Indian Journal of Psychological Medicine, 31(1), 35. https://doi.org/10.4103/0253-7176.53313

15. Dubey, A., \& Desetty, R. (2015). Neonatal care practices regarding traditional beliefs and customs adopted by slum families in Parbhani district. Advanced. Research Journal of Social Science, 6,1, 28-31.

16. Elliot, A. J., Maier, M. A., Moller, A. C., Friedman, R., \& Meinhardt, J. (2007). Color and psychological functioning: the effect of red on performance attainment. Journal of Experimental Psychology, 136, 1, 154-168

17. Ellison, C. G. (1991). Religious Involvement and Subjective Well-Being, Journal of Health and Social Behavior, 32, 80-99

18. Frank, R.H. (1988). Passions within Reason. New York: W.W. Norton \& Co

19. Furman, W., \& Buhrmester, D. (1992). Age and sex differences in perceptions of networks of personal relationships. Child Development, 63, 103-115.doi: 10.1111/j.1467- 8624.1992.tb03599.x

20. Galanaki, E. P. (2001). The imaginary audience and the personal fable in relation to risk behavior and risk perception during adolescence. Psychology: The Journal of the Hellenic Psychological Society, 8, 411-443

21. Gamlin, J. B. (2011). "My eyes are red from looking and looking": Mexican working children's perspectives of how tobacco labour affects their bodies. Vulnerable Children and Youth Studies, 6(4), 339-345. https://doi.org/10.1080/17450128.2011. 635222

22. Garbarino, J. (1999). The effects of community violence on children. Child Psychology, A Handbook of Contemporary Issues, ed. L Balter, C TamisLaMonda, (pp. 412-25). New York: Psychology Press

23. Garmezy, N. (1993). Children in poverty: resilience despite risk. Psychiatry, 56, 127-3

24. Gastaldo, D., Magalhães, L., Carrasco, C., and Davy, C. (2012). Body-Map Storytelling as Research: Methodological considerations for telling the stories of undocumented workers through body mapping. Retrieved from http://www.migrationhealth.ca/ undocumented-workers-ontario/body-mapping.

25. Harter, S. (1990). Causes, correlates, and the functional role of global self-worth: A life-span perspective. In J. Kolligian \& R. Sternberg (Eds.), Competence considered. New Haven, CT: Yale University Press.

26. Hemmings, P. (1995). Communicating with children through play. In Susan Smith \& Margaret Pennells
(Eds.), Interventions with bereaved children. London: Kingsley Publishers.

27. Hemphill, M. (1996). A note on adults' color-emotion associations. Journal of Genetic Psychology, 157, 275-281.

28. Hume, D. (2008). "Emotions and moods," in Organizational Behavior, 15th ed., S. P. Robbins and T. A. Judge, Eds., ch. 4, pp. 258-297.

29. Izard, C. E. (2007). Basic emotions, natural kinds, emotional schemas, and a new paradigm. Perspectives on Psychological Science, 2, $260-280$.

30. Jamadar, C., \& Sindhu, A. (2015). The Impact of Socio Economic Status on Emotional intelligence and Creativity among Tribal Adolescent Students. The International Journal of Indian Psychology, 3,1, DIP: C00113V3/1201

31. Kim, P., Evans, G. W., Angstadt, M., Ho, S. S., Sripada, C. S., Swain, J. E., ... Phan, K. L. (2013). Effects of childhood poverty and chronic stress on emotion regulatory brain function in adulthood. Proceedings of the National Academy of Sciences, 110(46), 18442-18447. https://doi.org/10.1073/ pnas. 1308240110

32. Krause, N. (1995a). Religiosity and Self-Esteem among Older Adults, The Journals of Gerontology: Series B, 50B, 5, P236-P246, https://doi.org/10. 1093/geronb/50B.5.P236

33. Krause, N. (2002b). Church-Based Social Support and Health in Old Age: Exploring Variations by Race, The Journals of Gerontology: Series B, 57, 6, S332-S347, https://doi.org/10.1093/geronb/57.6. S332

34. Krause, N. (2003c). Religious Meaning and Subjective Well-Being in Late Life, The Journals of Gerontology: Series B, 58, 3, S160-S170, https:// doi.org/10.1093/geronb/58.3.S160

35. Kumar, A., Asha Pathak, A., Kumar, S., Rastogi, P., \& Rastogi, P. (2012). The Problem of Child Sexual Abuse in India Laws, Legal Lacuna and the Bill PCSOB-2011. Journal Indian Academic Forensic Medicine, 34, 2.

36. Kundu, M. (1984). Tribal education in India: Some problems. Journal of Indian Education, 10, 1-7.

37. Lange, C.G. \& W. James (1967). The emotions. New York: Hafner.

38. Lanteigne, D. M. (2011). Patterns among emotional experience, arousal, and expression in adolescence (Unpublished master's dissertation). Queen's University, Canada.

39. Maslow, A. H. (1943). A theory of human motivation. Psychological Review, 50, 370-396.

40. Mayer, J., Salovey, P., \& Caruso, D. (2004). Emotional intelligence: Theory, findings, and implications. Psychological Inquiry, 15(3), 197-215.

41. MacLoyd,V .C. (1997). The impact of poverty and low socioeconomic status on the socio emotional 
functioning of African-American children and adolescents: mediating effects. Social and Emotional Adjustment and Family Relations in Ethnic Minority Families, (pp. 7-34.) Mahwah, NJ: Erlbaum.

42. Megbolugbe, I. F. and Linneman, P.D. (1993). Home ownership. Urban Studies 30, 659- 682 https://doi.org/10.1080/00420989320081861

43. Mitchell, L. M. (2006). Body and Illness: Considering Visayan Filipino Children's Perspectives within Local and Global Relationships of Inequality. Medical Anthropology, 25(4), 331-373. https://doi.org/10. 1080/ 01459740601025856

44. Mohammad, S. (2011). Colourful Language: Measuring Word-Colour Associations. Proceedings of the 2nd Workshop on Cognitive Modeling and Computational Linguistics, pages 97-106, Portland, Oregon, June 2011. c 2011 Association for Computational Linguistics.

45. Pollner, M. (1989). Divine Relations, Social Relations, and Well-Being. Journal of Health and Social Behavior, 30, 1, 92-104. Retrieved from http://www.jstor.org/stable/2136915

46. Poortinga, Y. H. (1992). Toward a conceptualization of culture for psychology. In S. Iwawaki, Y. Kashima, \& K. Leung (Eds.), Innovations in cross-cultural psychology (pp. 3-17). Amsterdam: Swets \& Zeitlinger.

47. Pope, D.J., Butler, H., \& Qualter, P. (2012). Emotional Understanding and Color-Emotion Associations in Children Aged 7-8 Years. Child Development Research Volume doi:10.1155/ 2012/975670

48. Renken, B., Egeland, B., Marvinney, D., Mangelsdorf, S., \& Sroufe, L.A. (1989). Early childhood antecedents of aggression and passivewithdrawal in early elementary school. Special Issue: Long-term stability and change in personality. Journal of Personality, 57, 257-281.

49. Robinson, N. S. (1995). Evaluating the nature of perceived support and its relation to perceived selfworth in adolescents. Journal of Research in Adolescence, 5, 253-280.

50. Romano, M.D. (1976) Preparing children for parental disability. Social Work in Health Care, 1, 309-315.

51. Russell, K., Wilson, M., \& Hall, R.E. (1992). The Color Complex: The Politics of Skin Color among African Americans. New York: Harcourt Brace Jovanovich.

52. Saarni, C. (2011). Emotional development in childhood. Encyclopedia on Early Childhood Development, 1-7.

53. Sampson, R.J. (1992). Family management and child development: insights from social disorganization theory. Advances in Criminological Theory. New Brunswick, NJ: Transaction Books.

54. Scheve, C.V., \& Luede, R.V. (2005). Emotion and Social Structures: Towards an Interdisciplinary Approach. Journal for the theory of Social Behavior, 35, 3, 0021-8308.

55. Schreuder, R. (2010). Unstacking the Deck: Rural Poverty and the Effects on Childhood Development. Michigan Journal of Social Work and Social Welfare, 1, 45-56.

56. Sibia, A., Misra, G., \& Srivastava, A.K. (2004). Towards understanding emotional intelligence in the Indian context: Perspectives of parents, teachers and children. Psychological Studies, 49, 114-123.

57. Silva, P. (2006). The Psychology of Emotions in Buddhist Perspective. Buddhist Publication Society, (BPS Online Edition).

58. Stets, J. E., \& Turner, J. H. (2014). Handbook of the Sociology of Emotions: Springer.

59. Telzer, E. H., Qu, Y., Goldenberg, D., Fuligni, A. J., GalvÃin, A., \& Lieberman, M. D. (2014). Adolescentsâ€ ${ }^{T M}$ emotional competence is associated with parentsâ $\epsilon^{\mathrm{TM}}$ neural sensitivity to emotions. Frontiers in Human Neuroscience, 8 https://doi.org/10.3389/fnhum.2014.00558

60. Veronneau, M., \& Dishion, T. J. (2010). Predicting change in early adolescent problem behavior in the middle school years: A mesosystemic perspective on parenting and peer experiences. Journal Abnormal Child Psychology, 38, 1125-1137. doi: 10.1007/s10802-010-9431-0

61. Wiesel, R., \& Daphna-Tekoha, S. (2000). The selfrevelation through color technique: understanding clients' relations with significant others, silent language, and defense mechanisms through the use of color. American Journal of Art Therapy, 39, 2, 35-41. 
APPENDIX I

Images of Participant Body Map

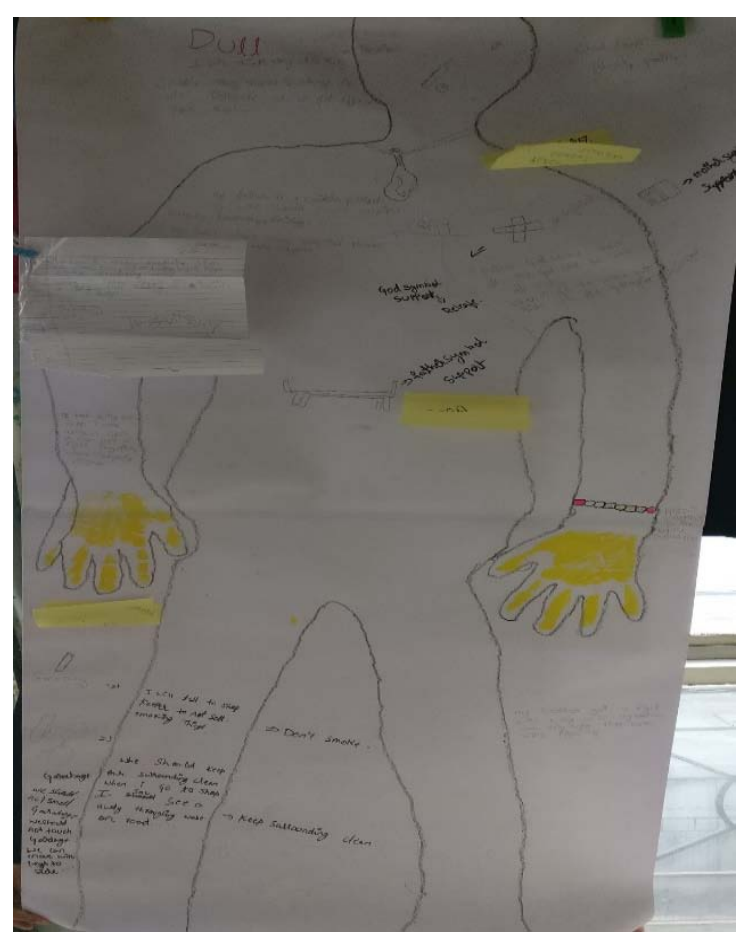

Image.1: Body map for participant 1

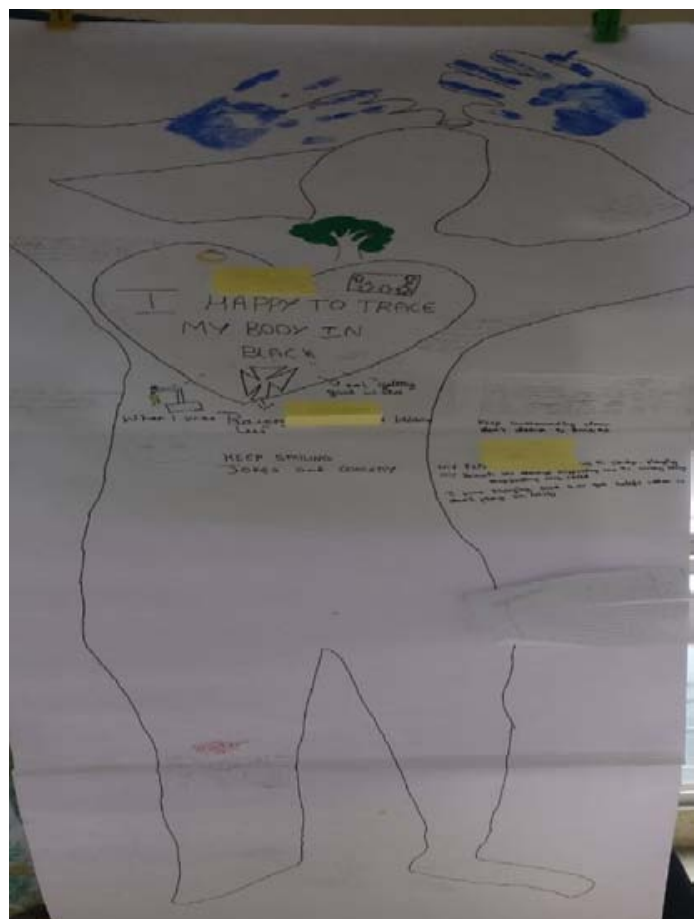

Image. 2: Body map for participant 2 


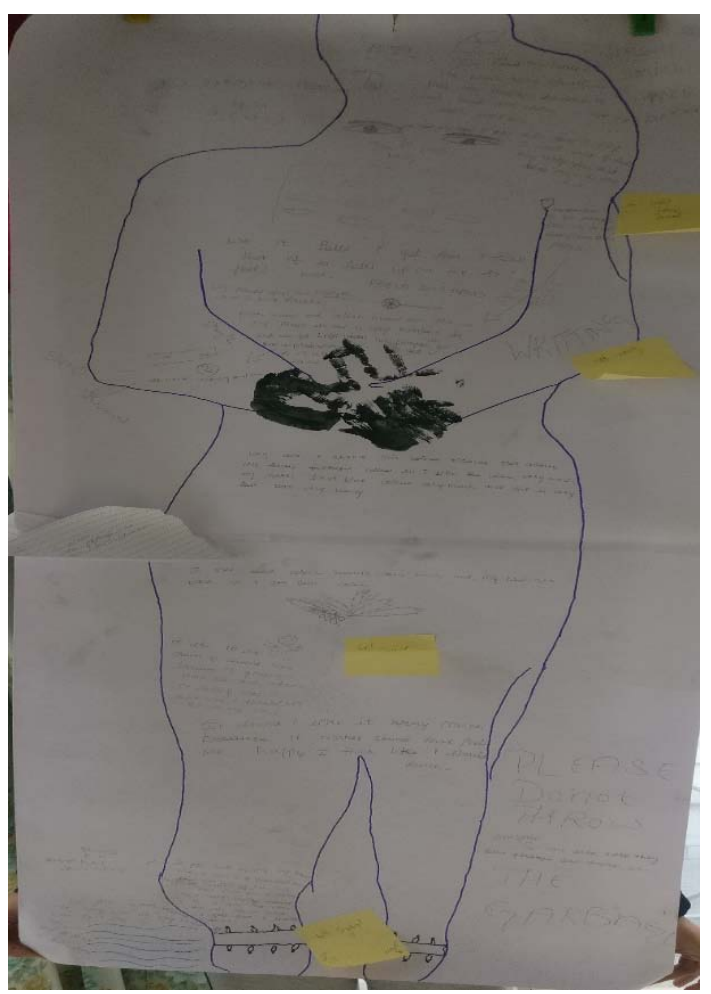

Image. 3: Body map for participant 3

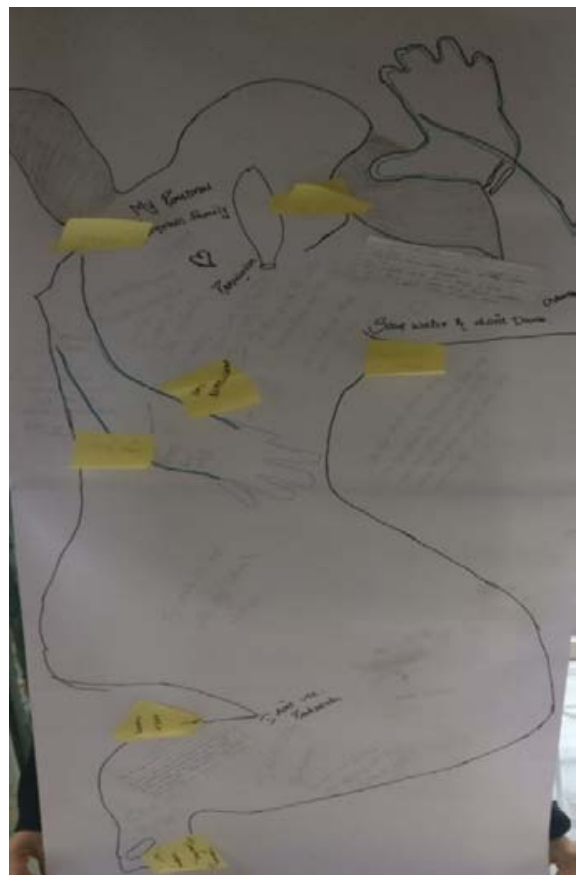

Image. 4: Body map for participant 4 


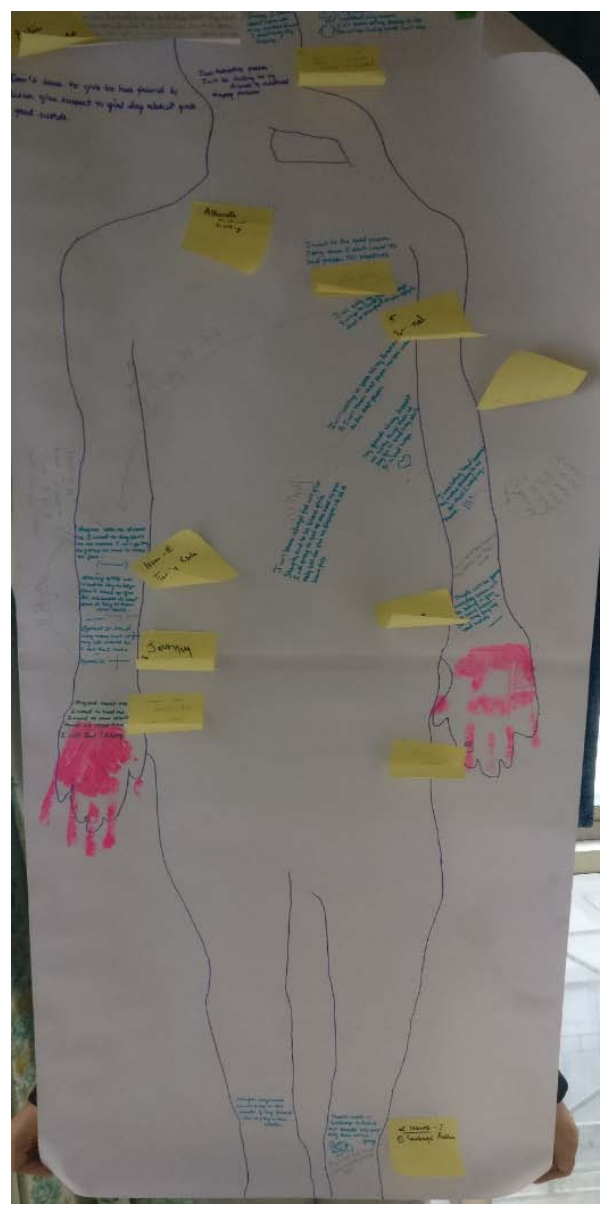

Image.5: Body map for participant 5

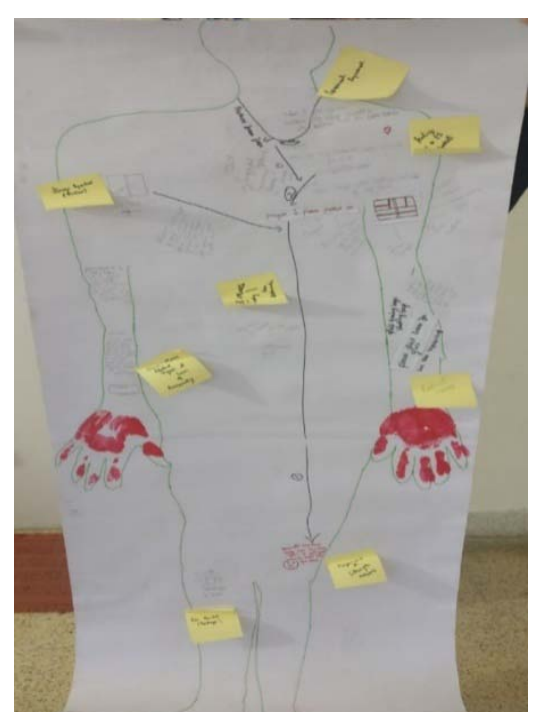

Image. 6: Body map for participant 6 


\section{Appendix II}

Tables of Participant Themes

Table 1: Individual themes for participant 1

\begin{tabular}{|c|c|c|c|}
\hline Themes & Sub- themes & $\begin{array}{l}\text { Quotes/ Remarks/ } \\
\text { Comments }\end{array}$ & Body Map Rep. \\
\hline \multirow[t]{2}{*}{ Black Color } & Dull & "Dull feel ho rahahai." & $\begin{array}{l}\text { writes "DULL" } \\
\text { with the color red }\end{array}$ \\
\hline & Skin Color & $\begin{array}{l}\text { "yeh color mere skin ki color } \\
\text { se matching rehtahai" }\end{array}$ & \\
\hline \multirow[t]{6}{*}{ Reflection of feelings } & Anger & $\begin{array}{l}\text { "Main humesha gusse mein } \\
\text { rehta hoon, isiliye" }\end{array}$ & \\
\hline & Happiness & $\begin{array}{l}\text { Conversations about friends } \\
\text { "mera mann happy!" }\end{array}$ & \\
\hline & & Bahut accha lagta hai - & \\
\hline & Upset/Sadness & $\begin{array}{l}\text { "mujhe bura lagta hai"- } \\
\text { Smoking "Pain sadness hai." }\end{array}$ & \\
\hline & Fear & $\begin{array}{l}\text { "Hum school se aate hai, toh } \\
\text { humein affect karta hai saas } \\
\text { lene mein. School jaate hai, } \\
\text { tab yeh sab liver ko jaata hai } \\
\text { aur poora damage karta hai. } \\
\text { Smoking ka pollution mujhe } \\
\text { kaha effect hota hai, mujhs } \\
\text { eaisa darr lagta hai." }\end{array}$ & \\
\hline & Pain and Suffering & $\begin{array}{l}\text { "main jab bhide kho yahaan } \\
\text { fighting hota hai, mujhe } \\
\text { bahut suffer hota hai. Mujhe } \\
\text { pain hota hai. Ek koek maar }\end{array}$ & \\
\hline \multirow[t]{2}{*}{ Defense Mechanism } & $\begin{array}{l}\text { Projection and } \\
\text { rationalization }\end{array}$ & $\begin{array}{l}\text { "Red color ke baarien mein } \\
\text { bataoga, ki bahut gussa } \\
\text { mein hai... Sab log jo yahan } \\
\text { rehte hai" } \\
\text { "bahaar toh ganda rehta hai, } \\
\text { andar achhaa rehta hai" }\end{array}$ & \\
\hline & Suppression & $\begin{array}{l}\text { Aur dard ke baarien mein } \\
\text { main sochta nahi. }\end{array}$ & \\
\hline Sensitivity/ Softness & & $\begin{array}{l}\text { "Mujhe toh sofa pasand } \\
\text { hai..usmein hi main daily } \\
\text { sota ho. Naram hai woh!" }\end{array}$ & $\begin{array}{l}\text { Home symbol - } \\
\text { stomach - drawn }\end{array}$ \\
\hline \multirow[t]{3}{*}{ Health } & Message & $\begin{array}{l}\text { "Mere papa ko daily dialysis } \\
\text { ke liye jaate hai" }\end{array}$ & Legs - written \\
\hline & & $\begin{array}{l}\text { "Smoking se humaarien } \\
\text { health ko problem hota" }\end{array}$ & $\begin{array}{l}\text { Fathers health - } \\
\text { chest ( written) }\end{array}$ \\
\hline & & $\begin{array}{l}\text { "don't smoke, } \quad \text { keep } \\
\text { surrounding clean" }\end{array}$ & \\
\hline Issues & Smoking & $\begin{array}{l}\text { "mera bhai ka friend aise hi } \\
\text { smoking karte hi margaya, } \\
\text { uske friends abhi hi karte hai } \\
\text { aur karte rehte hai" }\end{array}$ & $\begin{array}{l}\text { Near legs - } \\
\text { Outside body } \\
\text { near the leg, } \\
\text { drawn cig }\end{array}$ \\
\hline
\end{tabular}




\begin{tabular}{|c|c|c|c|}
\hline & & $\begin{array}{l}\text { "God ne banaya, kaiko } \\
\text { smoking karne waale. Kaun } \\
\text { hai yeh log jo ciggerette } \\
\text { banate hai? Gussa aata hai } \\
\text { kaun banata haiyeh sab" }\end{array}$ & \\
\hline & Fighting & $\begin{array}{l}\text { "yahaan pe toh hare k din ke } \\
\text { baad fighting hoti rehti hai" }\end{array}$ & $\begin{array}{ll}\text { Near legs } \\
\text { Written } \\
\text { near legs }\end{array}$ \\
\hline Marks & Tension & & Brain - written \\
\hline \multirow[t]{2}{*}{ Reality Vs Desire } & Garbage Vs cleanliness & $\begin{array}{l}\text { "toh yeh garbage yahi pe } \\
\text { rehta hai" "Na main ngo } \\
\text { mein rehta toh, toh mein } \\
\text { green color daalta, who } \\
\text { clean road rehti, acha rehta, } \\
\text { phool hota hai." } \\
\text { "wahan pe toh poora kachra } \\
\text { fail ke rehta hai. Usse dekhte } \\
\text { hi mann mera kya hai, } \\
\text { church ko bhiya haan aana } \\
\text { hai." }\end{array}$ & $\begin{array}{l}\text { Legs } \\
\text { (environmental } \\
\text { symbol) Slogan } \\
\text { related to it (next } \\
\text { to life symbol) }\end{array}$ \\
\hline & $\begin{array}{c}\text { Idealism } \\
\text { :Bravery/Honesty }\end{array}$ & $\begin{array}{l}\text { "Friend ne diya, friend } \\
\text { forever!" } \\
\text { "kabhi honesty rehna hai, } \\
\text { zyada bravery, aur, kya } \\
\text { kaam kare toh bhi honesty } \\
\text { se karna hai" }\end{array}$ & \\
\hline \multirow[t]{3}{*}{ Support/Strength } & God & $\begin{array}{l}\text { "Exam start karne se pehle } \\
\text { pray kar leta hoon" } \\
\text { "God haina. Main zyaada } \\
\text { believe karta hoon" }\end{array}$ & $\begin{array}{l}\text { Heart - plus sign } \\
\text { drawn }\end{array}$ \\
\hline & Friends & $\begin{array}{l}\text { "friends who mujhe honesty } \\
\text { dete hai" }\end{array}$ & $\begin{array}{l}\text { Hand - friendship } \\
\text { band }\end{array}$ \\
\hline & Parents & $\begin{array}{l}\text { "who jaise bolte hai, waise hi } \\
\text { karta hoon" }\end{array}$ & $\begin{array}{l}\text { Mother - shoulder } \\
\text { outside book } \\
\text { Father - sofa - } \\
\text { stomach }\end{array}$ \\
\hline \multirow[t]{2}{*}{ Coping/ distractibility } & Cricket & $\begin{array}{l}\text { "jab cricket koj aata ho, tab } \\
\text { yeh tension apnse alag } \\
\text { rakhta hoon" } \\
\text { "main bolna hai, ki tum jab } \\
\text { jab sad raho, tab who karo } \\
\text { jo pasand hai. Usse theek } \\
\text { lagta hai." }\end{array}$ & $\begin{array}{l}\text { Face - cricket bat } \\
\text { drawn on face }\end{array}$ \\
\hline & Need for achievement & $\begin{array}{l}\text { "Think karta rehta hoonki } \\
\text { match kaise jeetna hai" } \\
\text { "pehle mujhe full padhna } \\
\text { hai, fir paise kamaakar } \\
\text { daddy ka operation } \\
\text { karauga" }\end{array}$ & \\
\hline Transfer learning & Learned Behavior & $\begin{array}{l}\text { "Mere papa bolte hai, aur } \\
\text { bhi jane hai hospital hai, god } \\
\text { ko bolo sabke liye pray ko. } \\
\text { Sabke liye pray karo" }\end{array}$ & \\
\hline
\end{tabular}


Table 2: Individual themes for Participant 2

\begin{tabular}{|c|c|c|c|}
\hline Themes & Sub- themes & Quotes/Remarks/ Comments & Body Map Rep. \\
\hline Skin Color & Black & $\begin{array}{l}\text { "black color mein, mere ghar ka color } \\
\text { bhi black hai, bahaar bhi poora black } \\
\text { hai. Body bhi" }\end{array}$ & $\begin{array}{l}\text { Close to heart - } \\
\text { written }\end{array}$ \\
\hline Self as hero & & $\begin{array}{l}\text { "uske uppar baithne mein ek feel rehta } \\
\text { hai" }\end{array}$ & \\
\hline \multirow[t]{4}{*}{$\begin{array}{l}\text { Close Relationships } \\
\text { : Attachment }\end{array}$} & Parents & $\begin{array}{l}\text { "uss ring mein ma'am, meri daddy aur } \\
\text { mummy ka initial hai ma'am. ( } A \text { and } \\
\text { G)" } \\
\text { "main unko khoona nahi chahta } \\
\text { hoon." }\end{array}$ & $\begin{array}{l}\text { Ring - near to the } \\
\text { heart - refer to } \\
\text { coding single } \\
\text { sheet } \\
\text { Family photo } \\
\text { Personal }+ \\
\text { Home symbol }\end{array}$ \\
\hline & Area of living & $\begin{array}{l}\text { "Abhi main iss gali mein rehke, inn } \\
\text { human beings se baat karke, ek } \\
\text { relationship rehta. Dusra jagah jaata, } \\
\text { udhar kaun rehta toh maloom nahi } \\
\text { hota, toh baat karne mein bhi idhar } \\
\text { udhar nahi hota" } \\
\text { "Yahaan acha sirf relationship lagta } \\
\text { hai" }\end{array}$ & \\
\hline & Friends & $\begin{array}{l}\text { "one day I was angry with my friend, } \\
\text { so I did not speak to him and I was } \\
\text { very sad then" }\end{array}$ & $\begin{array}{l}\text { Outside } \\
\text { trace }\end{array}$ \\
\hline & Extended family & $\begin{array}{l}\text { "We all used to live together. That is } \\
\text { why. First we all could talk, baat kar } \\
\text { sakte hai. Ab toh koi nahi hai." }\end{array}$ & \\
\hline \multirow[t]{4}{*}{ Area } & Change & $\begin{array}{l}\text { "I will become very well, I will change } \\
\text { from the slum area" } \\
\text { "yahaan log ache nahi hai" }\end{array}$ & Chest - written \\
\hline & Fights & $\begin{array}{l}\text { "ghar mein reh toh neeche sound karti } \\
\text { hai, wahaan roz ladaai hoti hai gali } \\
\text { mein" } \\
\text { "All night disturbance." }\end{array}$ & \\
\hline & Trees & $\begin{array}{l}\text { "trees important hai lungs ke liye } \\
\text { breathing ke liye( starts drawing) near } \\
\text { the chest." }\end{array}$ & $\begin{array}{l}\text { Environmental } \\
\text { symbol - chest }\end{array}$ \\
\hline & Message & $\begin{array}{l}\text { "keep surrounding clean, don't drink } \\
\text { and don't smoke" }\end{array}$ & $\begin{array}{l}\text { Outside body - } \\
\text { written }+ \text { pasted }\end{array}$ \\
\hline \multirow[t]{3}{*}{$\begin{array}{l}\text { Reflection of } \\
\text { feelings }\end{array}$} & Anger & $\begin{array}{l}\text { "gussa aata hai" } \\
\text { "paani kaun dale gussa aaya tha" }\end{array}$ & \\
\hline & Loneliness & $\begin{array}{l}\text { Agreed to feel lonely - mentioned in } \\
\text { body map }\end{array}$ & \\
\hline & Sadness & Related to father's health & \\
\hline \multirow[t]{2}{*}{ Health } & Water Problem & $\begin{array}{l}\text { "paani baaraa bar nahi aata hai, aaye } \\
\text { toh not clean" }\end{array}$ & $\begin{array}{l}\text { Water tap drawn } \\
\text { - heart }\end{array}$ \\
\hline & Father & "my father is a dialysis patient" & \\
\hline
\end{tabular}




\begin{tabular}{|c|c|c|c|}
\hline & Self & $\begin{array}{l}\text { "not feeling well because of water } \\
\text { because colored water" }\end{array}$ & \\
\hline Marks & Suppression & $\begin{array}{l}\text { "bola toh darr rahe the, they will get } \\
\text { scared and scare me" }\end{array}$ & $\begin{array}{l}\text { Leg and hand - } \\
\text { drawn }\end{array}$ \\
\hline \multirow[t]{3}{*}{$\begin{array}{l}\text { Strength and } \\
\text { Support }\end{array}$} & Parents & $\begin{array}{l}\text { "bahut important hai, kyuki who aur } \\
\text { kisi ko nahi, humko beta bolkar } \\
\text { sunaate hai." }\end{array}$ & $\begin{array}{l}\text { Family symbol }+ \\
\text { personal symbol }\end{array}$ \\
\hline & Friends & $\begin{array}{l}\text { "friends are supporting me outside, } \\
\text { my body ( from outside)" }\end{array}$ & $\begin{array}{l}\text { Outside body } \\
\text { trace - written }\end{array}$ \\
\hline & God & $\begin{array}{l}\text { "kab se Jesus ki photo humaare in } \\
\text { ghar mein hai, tab se musibat kam } \\
\text { hai" }\end{array}$ & $\begin{array}{llr}\text { Heart } & - & \text { life } \\
\text { symbol } & - & \text { cross } \\
\text { drawn } & & \end{array}$ \\
\hline
\end{tabular}

Table 3: Individual themes for participant 3

\begin{tabular}{|c|c|c|c|}
\hline Themes & Sub themes & Quotes/Remark/Comments & Body Map Rep. \\
\hline Family Role Models & & $\begin{array}{l}\text { "I like my big sister very much } \\
\text { miss. So which color she likes, } \\
\text { I also like" }\end{array}$ & Elder sister \\
\hline \multirow[t]{6}{*}{ Expressed Emotions } & Aggression & $\begin{array}{l}\text { "I hit them, for girls, boys, } \\
\text { everybody" }\end{array}$ & \\
\hline & Happiness & $\begin{array}{l}\text { "if I am happy, ill not hit } \\
\text { anybody" }\end{array}$ & \\
\hline & Crying & \multirow{2}{*}{$\begin{array}{l}\text { "ill be sitting, ill be sitting } \\
\text { sadly, they'll ask, ill be not } \\
\text { saying. Then ill be crying, then } \\
\text { ill say miss" }\end{array}$} & written \\
\hline & Sadness & & \\
\hline & Writing & "ill be writing in book miss" & \\
\hline & Talking/Venting & $\begin{array}{l}\text { "what In my heart I said you all } \\
\text { and my heart is free" } \\
\text { Refer to memo for observation }\end{array}$ & \\
\hline \multirow[t]{2}{*}{ Need of Belonging } & Friends & $\begin{array}{l}\text { "in other areas there will not be } \\
\text { friends miss" } \\
\text { "then they'll fight for me so ill } \\
\text { think they are with me" }\end{array}$ & \\
\hline & Family & $\begin{array}{l}\text { "there are all our relations } \\
\text { miss" }\end{array}$ & \\
\hline \multirow[t]{2}{*}{ Social Judgement } & Fear & $\begin{array}{l}\text { "darr ho raha hai miss..galat } \\
\text { answer keh diya toh" }\end{array}$ & \\
\hline & Skin Color & $\begin{array}{l}\text { "hands are only black miss"; "I } \\
\text { am black in color miss" }\end{array}$ & \\
\hline \multirow[t]{2}{*}{ Personality } & Mood Swings & $\begin{array}{l}\text { "ill be, one minute ill be happy } \\
\text { miss, one time my mood will } \\
\text { be sad. One time my mood } \\
\text { will be angry, at that time } \\
\text { anybody will talk to me miss, ill } \\
\text { hit them miss." }\end{array}$ & $\begin{array}{l}\text { Anklet - wearing } \\
\text { since childhood } \\
\text { (simple) } \\
\text { Drawn with } \\
\text { black (sounds } \\
\text { connotes her } \\
\text { moods) - refer } \\
\text { to single code } \\
\text { sheet }\end{array}$ \\
\hline & Simplicity & "simple miss" & \\
\hline
\end{tabular}


Carefree presence

\begin{tabular}{|c|c|c|c|}
\hline & Carefree presence & $\begin{array}{l}\text { "I was thinking I should open it } \\
\text { and I should be free." }\end{array}$ & \\
\hline Status & & $\begin{array}{l}\text { "we don't have our own house } \\
\text { miss" } \\
\text { She wants a big house. }\end{array}$ & \\
\hline \multirow[t]{4}{*}{ House Problem } & Small (space) & $\begin{array}{l}\text { "for doing work it is very small } \\
\text { miss" }\end{array}$ & \multirow{3}{*}{$\begin{array}{l}\text { Walls (house is } \\
\text { small, not very } \\
\text { strong) - ches } \\
\text { (drawn) - home } \\
\text { symbol }\end{array}$} \\
\hline & Weak (Strength) & $\begin{array}{l}\text { "And the houses are not } \\
\text { strong" }\end{array}$ & \\
\hline & Fear & $\begin{array}{l}\text { "kahi mere uppar na gir jaaye, } \\
\text { darr lagta hai" }\end{array}$ & \\
\hline & Tension (mind) & "tension deti hai" & Brain - tension \\
\hline \multirow[t]{3}{*}{$\begin{array}{c}\text { Formal Operational } \\
\text { Issues }\end{array}$} & Self as Hero & $\begin{array}{l}\text { "Sitting on trees... Main apna } \\
\text { book yahaan rakhke padhti } \\
\text { hoon miss, wahaan fresh air } \\
\text { hota hai" } \\
\text { "In family no problem should } \\
\text { be there." }\end{array}$ & $\begin{array}{l}\text { Coconut trees - } \\
\text { Drawn } \\
\text { (stomach) } \\
\text { environmental } \\
\text { symbol }\end{array}$ \\
\hline & Idealism & $\begin{array}{l}\text { "if we do prayer know miss, if } \\
\text { anything we ask god will give } \\
\text { us" } \\
\text { "we can break this and } \\
\text { construct big house" }\end{array}$ & \\
\hline & Body Marks & "I feel bad that mark is there" & $\begin{array}{l}\text { Eyes and legs - } \\
\text { injury marks }\end{array}$ \\
\hline Cultural Factors & & $\begin{array}{l}\text { "we should take in our hand } \\
\text { and then only we should pray } \\
\text { miss." }\end{array}$ & Hand \\
\hline \multirow[t]{3}{*}{ Personal Challenges } & Financial Situation & \multirow{3}{*}{$\begin{array}{l}\text { "my mother has more fever, } \\
\text { more money we have } \\
\text { spended on it. My father and } \\
\text { me have more tension." } \\
\text { "she wants to me make doctor } \\
\text { but we don't have more } \\
\text { money" }\end{array}$} & \multirow[t]{3}{*}{$\begin{array}{l}\text { Hand - money } \\
\text { symbol drawn }\end{array}$} \\
\hline & Health & & \\
\hline & & & \\
\hline Issues (Garbage) & & $\begin{array}{l}\text { "in our area more they throw } \\
\text { garbage and smoke" }\end{array}$ & $\begin{array}{l}\text { Legs - public } \\
\text { message written }\end{array}$ \\
\hline \multirow[t]{4}{*}{ Support/Strength } & Friends & $\begin{array}{l}\text { "my friends they give me } \\
\text { strength" } \\
\text { "they are close with me, they'll } \\
\text { be there and helping me" }\end{array}$ & $\begin{array}{l}\text { Heart } \\
\text { friendship band }\end{array}$ \\
\hline & Family & "family, prayer and GOD miss" & Heart - written \\
\hline & God & & Hand - written \\
\hline & Heart & & \\
\hline
\end{tabular}


Table 4: Individual themes for participant 4

\begin{tabular}{|c|c|c|c|}
\hline Themes & Sub Themes & Quotes/Remarks/Comments & Body Map Rep \\
\hline \multirow[t]{4}{*}{ Personality Traits } & Shy & "main toh silent hi rehti hoon" & \\
\hline & \multicolumn{3}{|l|}{ Quiet } \\
\hline & Easily angered & \multicolumn{2}{|l|}{ "gussa bahut jaldi aata hai" } \\
\hline & Lacks Confidence & \multicolumn{2}{|l|}{ "humko toh himmat nahi," } \\
\hline \multicolumn{2}{|l|}{ Family } & $\begin{array}{l}\text { "Main family ke saath rehna hi pasand } \\
\text { karti hoon" }\end{array}$ & $\begin{array}{l}\text { Family } \\
+ \text { Life symbol } \\
\text { drawn } \quad \text { and } \\
\text { written }\end{array}$ \\
\hline Status & & \multicolumn{2}{|l|}{ "yeh toh humaara own house hai" } \\
\hline \multirow[t]{3}{*}{ Parenting } & Permission & \multicolumn{2}{|l|}{$\begin{array}{l}\text { "humko toh himmat nahi, humaare } \\
\text { mummy papa hi solve karte } \\
\text { hai..humaare mummy papa jis time par } \\
\text { baat karte hai uss time hum baat nahi } \\
\text { karte.." } \\
\text { "mere ma baap hi toh mera sahara hai, } \\
\text { inke permission ke bina main kahaan }\end{array}$} \\
\hline & Protection & $\begin{array}{l}\text { "Humaare mummy papa toh relative ke } \\
\text { ghar tak nahi bhejte humein" }\end{array}$ & $\begin{array}{l}\text { Black } \\
\text { neck, } \\
\text { ankle }\end{array}$ \\
\hline & Beliefs + Safety & $\begin{array}{l}\text { "jab bahaar nikalti toh log nazar lagaate } \\
\text { hai toh black color bahut pinaate hai } \\
\text { mummy papa" } \\
\text { "koi bhi dekar mujhe nazar na lage } \\
\text { isiliye pasand hai. Mere mummy papa } \\
\text { ko bhi isiliye pasand hai." }\end{array}$ & \\
\hline \multirow[t]{2}{*}{ Strong Attachment } & Parents & $\begin{array}{l}\text { "jab bhi mummy aunty kaam kar rhi hai, } \\
\text { mere mummy papa bolte haij ao tum so } \\
\text { jao, isiliye takleef hoti hai" } \\
\text { "main bhi dekh kar unko roti hoon.." } \\
\text { "Meri family toh humesha mere support } \\
\text { karte hai, koi takleef nahi dete hai. Meri } \\
\text { family sab kuch mere hai. Aur friends } \\
\text { jab bhi main udaas hoti hoon toh wohi } \\
\text { mujhe hasate hai, aur wohi mera } \\
\text { problem solve karte hai.." }\end{array}$ & Heart - Written \\
\hline & Friends & $\begin{array}{l}\text { "yeh nishaan dekhti hoon woh hi yaad } \\
\text { aate hai samreen" }\end{array}$ & "Don" \\
\hline \multirow[t]{2}{*}{$\begin{array}{l}\text { Expressed } \\
\text { Emotions }\end{array}$} & Self-Harm & $\begin{array}{l}\text { "jab mere friends mere se baat nahi kar } \\
\text { rahe the, gussa ho gaye "the, toh unki } \\
\text { tension mein maine kaat li thi" }\end{array}$ & $\begin{array}{l}\text { Right hand - } \\
\text { Pencil sign of a } \\
\text { line made on } \\
\text { the wrist of right } \\
\text { hand }\end{array}$ \\
\hline & Crying & "jab main rotti hoon" & $\begin{array}{l}\text { Right hand next } \\
\text { to cut }\end{array}$ \\
\hline
\end{tabular}




\begin{tabular}{|c|c|c|c|}
\hline $\begin{array}{c}\text { Defense } \\
\text { Mechanism }\end{array}$ & Suppression & $\begin{array}{l}\text { "aur dil mein rakhke roti hoon aur } \\
\text { dusron ko nahi bolti.." } \\
\text { "jab main rotti hoon, toh woh rote hai, } \\
\text { nahi dekh paayegey, isiliye ma'am.. } \\
\text { unhe takleef hoti hai isiliye main nahi bol } \\
\text { paati.." }\end{array}$ & \\
\hline \multirow[t]{4}{*}{$\begin{array}{l}\text { Reflection of } \\
\text { feelings }\end{array}$} & Sad VS Happy & $\begin{array}{l}\text { "mujhe bura lagta hai" } \\
\text { inte din nahi baat kare, isiliye sad..itne } \\
\text { din baat kare nahi kare aur ab kar rahe } \\
\text { hai...isiliye happy! }\end{array}$ & \\
\hline & Anger & & \\
\hline & Fear & $\begin{array}{l}\text { "jab toh main nahi bol paati, darr lagta } \\
\text { hai, nahi bol paati main" }\end{array}$ & \\
\hline & Guilt & Refer to memo - parental pride & \\
\hline \multirow[t]{3}{*}{ Issues } & Fights & $\begin{array}{l}\text { "yahaan toh full ladte rehte hai jhagarte } \\
\text { rehte hai" }\end{array}$ & $\begin{array}{l}\text { Legs - "I don't } \\
\text { like fighting" }\end{array}$ \\
\hline & $\begin{array}{c}\text { Abusive } \\
\text { Communication }\end{array}$ & $\begin{array}{l}\text { "mujhe toh bachpan se hi bad words } \\
\text { aur fighting pasand nahi hai isiliye main } \\
\text { pairon pe lagaai" }\end{array}$ & $\begin{array}{l}\text { Environmental } \\
\text { Symbol }\end{array}$ \\
\hline & Alcoholism & $\begin{array}{l}\text { "people will drink alcohol and they fill } \\
\text { fight more in our area.." } \\
\text { "main bhi chahti hoon ki humaare area } \\
\text { mein aur relatives alcohol kam karde" }\end{array}$ & \\
\hline Thoughtful & & $\begin{array}{l}\text { "main sochti hoon unko badalna chahti } \\
\text { hoon" }\end{array}$ & \\
\hline Ideal & & $\begin{array}{l}\text { "ki bad words nahi use karna, yeh toh } \\
\text { galat baat hai.." }\end{array}$ & Legs - Slogan \\
\hline
\end{tabular}

Table 5: Individual Themes for Participant 5

\begin{tabular}{|c|c|c|c|}
\hline Themes & Sub Themes & Quotes/Remarks/Comments & Body Map Rep \\
\hline \multirow[t]{4}{*}{ Expressed Emotions } & Self-Harm & $\begin{array}{l}\text { "i cut it here hand because my } \\
\text { mother was scolding to me" }\end{array}$ & Hand - Drawn \\
\hline & Crying & $\begin{array}{l}\text { "ill be crying why they'll be } \\
\text { doing for me" }\end{array}$ & $\begin{array}{l}\text { Hand - slap } \\
\text { them! }\end{array}$ \\
\hline & Writing & $\begin{array}{l}\text { "any problems i will be writing } \\
\text { my problem, full of a paper i } \\
\text { will be writing my problem and } \\
\text { then i will tearing paper or fire } \\
\text { in i will burn it" }\end{array}$ & $\begin{array}{l}\text { Heart } \\
\text { emotions arise }\end{array}$ \\
\hline & Self-Talk & Look into the mirror in her room & \\
\hline \multirow[t]{2}{*}{ Relationships } & Relatives & $\begin{array}{l}\text { "uncles and aunties, I want to } \\
\text { talk to them. III not be talking. III } \\
\text { be scared with them." }\end{array}$ & $\begin{array}{l}\text { Heart }- \text { blue } \\
\text { color }\end{array}$ \\
\hline & Friends & $\begin{array}{l}\text { "They know more about me } \\
\text { than I know." }\end{array}$ & \\
\hline Self- Identity & SES & "I am little bit middle class" & \\
\hline \multirow[t]{2}{*}{ Need for Achievement } & Pride & "because of mother only I am & \\
\hline & Education & $\begin{array}{l}\text { getting education also. } \\
\text { Because of mother only I was } \\
\text { proud of my mother." }\end{array}$ & \\
\hline
\end{tabular}




\begin{tabular}{|c|c|c|c|}
\hline \multirow[t]{4}{*}{ Issues } & Molestation & $\begin{array}{l}\text { "they will touch plus I will feel } \\
\text { bad.." }\end{array}$ & $\begin{array}{l}\text { Hand - slap } \\
\text { them! (green } \\
\text { color - does not } \\
\text { like green color) }\end{array}$ \\
\hline & Eve Teasing & $\begin{array}{l}\text { "they are also having brothers } \\
\text { and sisters why they will tease } \\
\text { for us" }\end{array}$ & \multirow{2}{*}{ 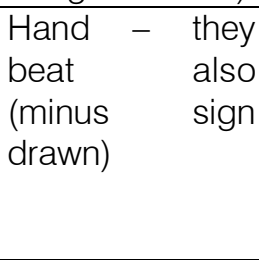 } \\
\hline & Fights & $\begin{array}{l}\text { "in this area bad people will be } \\
\text { eating ganda.. they will be } \\
\text { fighting" }\end{array}$ & \\
\hline & Garbage & $\begin{array}{l}\text { "we want to tell to people dont } \\
\text { put garbage in the area, we } \\
\text { want to say to them" }\end{array}$ & Legs - Drawn \\
\hline \multirow[t]{4}{*}{$\begin{array}{l}\text { Ideal VS Real Self } \\
\text { Concept }\end{array}$} & Self-blame & $\begin{array}{l}\text { "now I was thinking because of } \\
\text { I did mistakes my mother will } \\
\text { get a bad name" }\end{array}$ & \\
\hline & Embarrassment & $\begin{array}{l}\text { "I was feeling bad about myself } \\
\text { i feel shame. why miss, their } \\
\text { mother also scold them they } \\
\text { did not cut their hand" }\end{array}$ & \\
\hline & Objectifying & $\begin{array}{l}\text { "No symbol in my body, I don't } \\
\text { like anything.. this mean... } \\
\text { no one makes me feel that.." }\end{array}$ & \\
\hline & Bravery & "I want to be brave." & \\
\hline \multirow[t]{4}{*}{$\begin{array}{c}\text { Strength VS } \\
\text { Helplessness }\end{array}$} & Lack of Support & $\begin{array}{l}\text { "I want to say why are you not } \\
\text { helping one girl.. but I can't do } \\
\text { anything about it.." }\end{array}$ & \\
\hline & $\begin{array}{l}\text { Girl Child/ Household } \\
\text { Chores }\end{array}$ & $\begin{array}{l}\text { "they were saying wash the } \\
\text { vessels, then wash clothes all } \\
\text { that they were saying..i am not } \\
\text { interested in all this work" }\end{array}$ & \\
\hline & Myself & $\begin{array}{l}\text { "myself only I am only getting } \\
\text { this strength" }\end{array}$ & $\begin{array}{l}\text { Stomach } \\
\text { written }\end{array}$ \\
\hline & God & & Heart - Slogan \\
\hline \multirow[t]{3}{*}{ Reflection of Feelings } & Fear & $\begin{array}{l}\text { "in my area I am full scared.. in } \\
\text { my area full of scared when } \\
\text { they'll beat me" }\end{array}$ & \\
\hline & Sadness & $\begin{array}{l}\text { "anyone touch me that time ill } \\
\text { be sad" } \\
\text { Discomfort while tracing of } \\
\text { body }\end{array}$ & \\
\hline & Anger & $\begin{array}{l}\text { "I will get angry means, I want } \\
\text { to beat them.." }\end{array}$ & \\
\hline \multirow[t]{2}{*}{$\begin{array}{l}\text { Black and White } \\
\text { Concepts/ Polarized } \\
\text { Thinking/ Idealism }\end{array}$} & Positivism VS Negativism & $\begin{array}{l}\text { "I didn't do positive things, but } \\
\text { ill choose in my life there } \\
\text { should be positive things... } \\
\text { they will say negative things } \\
\text { and bad words they will say. for } \\
\text { that symbol also i put negative, } \\
\text { minus sign.." }\end{array}$ & $\begin{array}{l}\text { Plus sign }- \\
\text { symbol life }\end{array}$ \\
\hline & Death & $\begin{array}{l}\text { "oh I want to die sometimes ill } \\
\text { be thinking.." }\end{array}$ & \\
\hline Defense Mechanism & Reaction Formation & $\begin{array}{l}\text { "no important and special ill } \\
\text { not feel.." }\end{array}$ & \\
\hline
\end{tabular}




\begin{tabular}{cl}
\hline Suppression & $\begin{array}{l}\text { "today III say, then I cant tell } \\
\text { this to anyone (laughs) ill feel } \\
\text { bad for that" }\end{array}$ \\
\hline Hope $\begin{array}{c}\text { Change/ } \\
\text { Intellectualization I am feeling.. they'll do all } \\
\text { this I don't know. But some } \\
\text { boys can do this" }\end{array}$ \\
\hline
\end{tabular}

Table 6: Individual themes for participant 6

\begin{tabular}{|c|c|c|c|}
\hline Themes & Sub-themes & Quote / Remarks & $\begin{array}{l}\text { Body Map } \\
\text { Rep }\end{array}$ \\
\hline \multirow[t]{3}{*}{ Attachment/Support } & Deceased Friend & $\begin{array}{l}\text { "who meri best friend thi usne chhod } \\
\text { diya,. Uhh, uska death ho gaya"; } \\
\text { Body map outline with light green as } \\
\text { deceased friends favourite color }\end{array}$ & $\begin{array}{l}\text { Bodytraced } \\
\text { outline } \\
\text { color - light } \\
\text { green }\end{array}$ \\
\hline & Parents & $\begin{array}{l}\text { "humaare parents bahut khush rakhte hai } \\
\text { humein, koi dukh nahi dete, koi mushkil } \\
\text { nahi padane dete" } \\
\text { "mummy bolti hai rone ko jaise main tere } \\
\text { saath hoon... mere saath koi aur hai, aisa } \\
\text { mehsoos hota hai" }\end{array}$ & $\begin{array}{l}\text { Heart; } \\
\text { Happy - } \\
\text { someone } \\
\text { is with me }\end{array}$ \\
\hline & Dad's Wallet & $\begin{array}{l}\text { "usmein kuch yaad gaar hai who } \\
\text { bachpan ke (smiling) wageera wagera } \\
\text { kuch humaarien papa ne sambhaal ke } \\
\text { wallet mein rakha hai" } \\
\text { "bachapn ki yaadien, parents ka pyaar, } \\
\text { sab kuch hai, jab main giri toh rote hai.." }\end{array}$ & $\begin{array}{l}\text { Heart, } \\
\text { Pasted } \\
\text { Cutting of } \\
\text { the symbol } \\
\text { (drawn as } \\
\text { homework) }\end{array}$ \\
\hline \multirow[t]{4}{*}{ Protection } & Taveez & $\begin{array}{l}\text { "darrlagne se aur kuch bhi problem ho } \\
\text { toh main isske saath rehti hoon" }\end{array}$ & $\begin{array}{l}\text { Neck } \\
\text { Black } \\
\text { threaded } \\
\text { chain }\end{array}$ \\
\hline & Kuran & $\begin{array}{l}\text { "humaaren ghar ko protect karta hai aur } \\
\text { humein bahut pasand hai" }\end{array}$ & $\begin{array}{l}\text { Right Hand } \\
- \text { read it } \\
\text { using that } \\
- \text { family } \\
\text { symbol of } \\
\text { protection } \\
\text { (drawn) }\end{array}$ \\
\hline & Slogan - Prayer & "please protect me" & $\begin{array}{l}\text { Heart - } \\
\text { written this! }\end{array}$ \\
\hline & Accompanied & Refer to memo & \\
\hline Financial Situation & Spouse Conflict & $\begin{array}{l}\text { "mujhe acha nahi lagta jab husband wife } \\
\text { ladte hai paison ke liye"; } \\
\text { "who dono baat nahi karte, aur mummy } \\
\text { khaana nahi khaati" } \\
\text { "Who sirf ladte hai, paise paise karte hai } \\
\text { toh humein bezaarlagtahai. Aur who jab } \\
\text { baat nahi karte tab hum unko milaane ki } \\
\text { koshish karte hai( smiles)"; } \\
\text { Participant feels upset and engages in } \\
\text { patching them up }\end{array}$ & $\begin{array}{l}\text { Hands } \\
\text { used for } \\
\text { exchange } \\
\text { of money : } \\
\text { Symbol of } \\
\text { Money } \\
\text { Drawn }\end{array}$ \\
\hline Girl child & $\begin{array}{l}\text { Household chores } \\
\text { Burnt mark }\end{array}$ & $\begin{array}{l}\text { "jab hum roti bana rahe the tab huayeh, } \\
\text { who roti paltaate hai na, tab tavaa lag } \\
\text { gaya tha" }\end{array}$ & $\begin{array}{l}\text { Left hand } \\
\text { elbow - } \\
\text { Crying }\end{array}$ \\
\hline
\end{tabular}




\begin{tabular}{|c|c|c|c|}
\hline & Guilt & $\begin{array}{l}\text { "beti hoon na isiliye" } \\
\text { "Mujhe guilty feel hota hai..meri shaadi ke } \\
\text { liye na isiliye" }\end{array}$ & $\begin{array}{l}\text { Hand - } \\
\text { money } \\
\text { !Guilty - } \\
\text { concerns } \\
\text { of my } \\
\text { marriage } \\
\text { as a } \\
\text { daughter, }\end{array}$ \\
\hline & Stomach pain & $\begin{array}{l}\text { nobody understands the pain she goes } \\
\text { through when stomach hurts }\end{array}$ & $\begin{array}{l}\text { Stomach - } \\
\text { Written }\end{array}$ \\
\hline Courage/strength & Burkha & $\begin{array}{l}\text { "burkha jab koi buri nazar se dekhe toh } \\
\text { humein bachata hai" }\end{array}$ & $\begin{array}{l}\text { Protect } \\
\text { from evil } \\
\text { eyes } \\
\text { (shares } \\
\text { important } \\
\text { than life) - } \\
\text { Refer to } \\
\text { first } \\
\text { individual } \\
\text { coding } \\
\text { guide }\end{array}$ \\
\hline \multirow[t]{3}{*}{$\begin{array}{l}\text { Eve teasing } \\
\text { (personal } \\
\text { experience) }\end{array}$} & Anger & $\begin{array}{l}\text { "kyu kiitna gussaaa tahai unn par (facial } \\
\text { expression of extreme disgust).. ek shatt } \\
\text { maaro (giggles)" }\end{array}$ & $\begin{array}{l}\text { Left Thigh - } \\
\text { Written } \\
\text { Red color } \\
\text { pen + Sad }\end{array}$ \\
\hline & Fear & $\begin{array}{l}\text { "mujhe bahut jaldi darr lagta hai } \\
\text { haan" } \\
\text { "Ek din main jaa rahi thi toh do teen ladko } \\
\text { ne mujhe cherha tha. Ekkaanjaryeh, } \\
\text { biryani pakaaigi, what kya kya kehke bol } \\
\text { rahe the. Isiliye main unke liye message } \\
\text { de rahi thi" }\end{array}$ & $\begin{array}{l}\text { Face } \\
\text { Drawn }\end{array}$ \\
\hline & Helplessness & $\begin{array}{l}\text { "hum kuch nahi kar sakte"; } \\
\text { "jab kisiko ladta hua dekhe toh mann } \\
\text { karta hai bolne ka first ki mat ladhiye. } \\
\text { Ladko ko toh hum nahi bol sakte, par } \\
\text { mummy daddy ko hum bolte hai. Please } \\
\text { don't fight" }\end{array}$ & \\
\hline $\mathrm{EE}$ & Crying & "allah se bolkar ro dogi" & \\
\hline $\begin{array}{c}\text { Meaning } \\
\text { Making/Significance }\end{array}$ & $\begin{array}{c}\text { Draws connections } \\
\text { Comparison/appearance } \\
\text { of body mark }\end{array}$ & Refer to memo & \\
\hline
\end{tabular}


Table 7: Master themes table

\begin{tabular}{ccl}
\hline Category & Master Themes & \multicolumn{1}{c}{ Findings } \\
\hline Emotional Personality & Emotions & $\begin{array}{l}\text { Anger, Sadness, Fear } \\
\text { Self-conscious emotions : shame } \\
\text { and guilt }\end{array}$ \\
\cline { 2 - 3 } & & Black and red color \\
\hline Emotional Triggers & Stressful life Events & $\begin{array}{l}\text { Financial Situations and Health } \\
\text { Concerns }\end{array}$ \\
\cline { 2 - 3 } & Issues of the Area & Eve-teasing, Fights, Garbage \\
\cline { 2 - 3 } & Challenged Needs & Security and Safety Needs \\
\hline Emotional Regulation & Defense Mechanisms & $\begin{array}{l}\text { Suppression, Rationalization, } \\
\text { Isolation, Projection, }\end{array}$ \\
\hline Emotional Expression & Crying & $\begin{array}{l}\text { Stressful and } \\
\text { Scenarios }\end{array}$ \\
\hline Coping Strategies & Aggression & Fights and Self-Harm \\
\hline & Support Network & Family Members and Peers \\
\cline { 2 - 3 } & Religiosity & Faith and Prayer \\
\cline { 2 - 3 } & Personality Characteristics & Emotional Sharing \\
\hline
\end{tabular}

